\title{
Fluctuating asymmetry of three bat species in extensive livestock systems from Córdoba department, Colombia
}

\author{
Asimetría fluctuante de tres especies de murciélagos en sistemas \\ de ganadería extensiva del departamento de Córdoba, Colombia
}

\author{
Dennis Castillo-Figueroa Biol, Ecol.
}

\section{KEYWORDS:}

Wing morphology; Artibeus planirostris; Artibeus lituratus; Carollia perspicillata; tropical dry-forest; sexual dimorphism.

PALABRAS CLAVE:

Morfología alar; Artibeus planirostris; Artibeus lituratus; Carollia perspicillata; bosque seco-tropical; dimorfismo sexual.

\section{ABSTRACT}

The aim of this study was to analyze the degree of fluctuating asymmetry in wing traits and digits of three common bat species (Artibeus lituratus, Artibeus planirostis and Carollia perspicillata) in extensive livestock systems from Córdoba department, Colombia. To do this, specimens from the Mammalian Collection at the Museo Javeriano de Historia Natural of Pontificia Universidad Javeriana (Bogotá, Colombia) were analyzed. All specimens belonged to fragments of tropical dry-forest immersed in extensive livestock systems of Córdoba department. To parse out fluctuating asymmetry, 11 wing traits were used. To assess the existence of asymmetry, nonparametric $U$ test was applied. Finally, to evaluate the existence of significant differences among digits, nonparametric one-way analysis of variance were carried out. In total, 114 specimens were analyzed $(A$. planirostris $=40, A$. lituratus $=33$, C. perspicillata $=41)$. The results showed no statistical differences $(p>0.05)$ in most of wing traits. Little variation in wing traits was due to its relevance on flight performance and the high tolerance to perturbation of these bat species. "Differential-mortality" hypothesis and "Big Mother" hypothesis are discussed. Results from this work suggest that livestock systems do not severely affect these species. Further studies should consider the type of management to know which one provides better conditions for bats.

\section{RESUMEN}

El objetivo de este estudio fue analizar el grado de asimetría fluctuante en los rasgos alares y en los dígitos de tres especies comunes de murciélagos (Artibeus lituratus, Artibeus planirostis y Carollia perspicillata) en sistemas ganaderos extensivos del departamento de Córdoba, Colombia. Para esto, se analizaron ejemplares de la Colección de Mamíferos del Museo Javeriano de Historia Natural de la Pontificia Universidad Javeriana (Bogotá, Colombia). La asimetría fluctuante se evaluó usando 11 rasgos alares. Para evaluar la existencia de asimetría, se usaron contrastes no paramétricos. Finalmente, se realizaron análisis no paramétricos de varianza con el fin de evaluar si existían diferencias entre los dígitos. En total, 114 ejemplares fueron analizados ( $A$. planirostris $=40, A$. lituratus $=33, C$. perspicillata $=41)$. Los resultados no mostraron diferencias estadísticas $(p>0.05)$ para la mayoría de rasgos alares. La poca variación alar se debió a su importancia en el vuelo y a la alta tolerancia de estas especies a la perturbación. Las hipótesis de "Mortalidad diferencial" y "Gran madre" son discutidas. Los resultados de este trabajo sugieren que los sistemas ganaderos no afectan severamente a estas especies. Futuros estudios deberían considerar el tipo de manejo para conocer cuál proporciona mejores condiciones para los murciélagos.
INFORMACIÓN

Recibido: 26-01-2018;

Aceptado: $17-06-2018$.

Correspondencia autor:

dennis.castillof@gmail.com 


\section{INTRODUCTION}

Nowadays, several anthropogenic pressures are jeopardizing animal populations (CEBALLOS et al., 2017). Environmental changes caused by landscape transformation may disrupt homeostasis affecting individual fitness of vertebrate populations (CODA et al., 2016; LAZIC et al., 2013). Particularly, livestock systems have been increasing in the last few decades and is likely to increase in the future, threatening biodiversity in developing countries (THORNTON et al., 2009). However, studies assessing the stress of animal species in livestock systems are scarce, especially in some Neotropical countries such as Colombia.

One of the approaches to evaluate the degree of stress of animal species is the Fluctuating asymmetry (FA), which is defined as the random deviations from perfect symmetry (e.g. radial, dihedral, rotational, bilateral) in populations of organisms (GRAHAM et al., 2010). FA can serve as a useful indicator of developmental instability, reflecting environmental and genetic stress of organisms (LEARY and ALLENDORF, 1989). For instance, species under environmental stress such as decreased food availability (WAUTERS, 1996), agrochemicals (CODA et al., 2016), and pathogens (ST- AMOUR et al., 2010), have higher levels of asymmetry. In addition, the decline of heterozygosity has an inverse relation to the levels of FA; in this sense, as heterozygosity decreases, FA increases (MESSIER and MITTON, 1996). Accordingly, FA seems to provide an adequate measure of stress since it has been useful in the evaluation of anthropogenic pressures on different animal groups such as insects (FLOATE and FOX, 2000), birds (LENS et al.,1999), amphibians (STAMOUR et al., 2010), reptiles (LAZIC et al., 2013) and mammals (CODA et al., 2016; WAUTERS, 1996).

Within mammals, bats are the unique taxonomic group with the ability for powered flight (CAMARGO and OLIVEIRA, 2012). To achieve this, bats have an integrated and multivariate fight apparatus: the wings (NORBERG and RAYNER, 1987). This structure is a special modification of forelimbs, characterized by a membrane of skin (dactylopatagia), stretched between elongated digits (digits II-V) (Wang et al., 2010). Although some studies have analyzed morphological differences in bat wings according to ecological characteristics (MARINELLO and BERNARD, 2014; NORBERG and RAYNER, 1987), differences in both intraspecific level and wing regions need more attention (STEVENS et al., 2013; CAMARGO and OLIVEIRA, 2012; FIGUEIREDO et al., 2015). For example, variation between sexes in terms of wing traits (i.e. sexual dimorphism) and variation among digits are poorly known.

The Caribbean region of Colombia is one of the most biodiverse in the country (RANGEL-CH, 2015). A priority ecosystem for conservation in this region is the tropical dry-forest, due to the historical loss of $92 \%$ of its original coverage (GÓMEZ and MORENO, 2016). Moreover, according to IUCN's Red List of Ecosystems criteria, it has been classified as critically endangered ecosystem (CR) (ETTER et al., 2015), and one of the mainly factors of its historic transformation is the expansion of livestock systems (PIZANO and GARCIA, 2014).

Particularly, in Cordoba department different studies have been done with bats in fragments of tropical dry-forest immersed in matrices of extensive livestock systems, analyzing ectoparasites load (CALONGE, 2012), reproductive phenology (VELA-VARGAS, 2013), and the structure of bat assemblages (BALLESTEROSCORREA, 2015). In these studies, Artibeus lituratus, Artibeus planirostris, and Carollia perspicillata are the species with the highest abundances in the assemblages. Furthermore, these species are involved in key roles such as seed dispersers of pioneering plants (e.g. Ficus, Cecropia, Solanum), enhancing the reforestation of disturbed areas in tropical dry-forest (RÍOS-BLANCO, 2010). Nevertheless, it is unknown the degree of environmental stress that these bat species are facing in extensive livestock systems, which are quite common in the Caribbean region. The use of FA can be an important tool for this purpose, especially in key structures like bat 
wings. Therefore, the present study aimed to assess the degree of FA in wing traits (i.e. metacarpals and phalanges) and the digits (i.e. III digit, IV digit, and $V$ digit) of $A$. lituratus, A. planirostis and C. perspicillata, using specimens collected in fragments of tropical dry-forest immersed in extensive livestock systems of Cordoba department. Sexual dimorphism is also evaluated in terms of wing traits for each one of the bat species.

\section{MATERIALS AND METHODS.}

Study site. Bat specimens from the Mammalian Collection at the Museo Javeriano de Historia Natural Lorenzo Uribe Uribe S. J. (MPUJ-MAMM) of Pontificia Universidad Javeriana (Bogotá, Colombia) were analyzed. All specimens belonged to fragments of tropical dry-forest immersed in extensive livestock systems of Cordoba department. Livestock systems had conventional and silvopastoral management. The localities of the specimens were: Betanci-Guacamayas

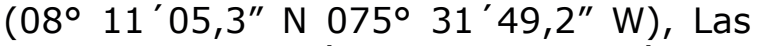
Palmeras (08 $30^{\circ} 37,1^{\prime \prime} \mathrm{N} 076^{\circ} 06^{\prime \prime} 12,9^{\prime \prime}$ W), Chimborazo $\left(08^{\circ} 44^{\prime} 32,4^{\prime \prime} 076^{\circ}\right.$ $\left.19^{\prime} 23,4^{\prime \prime} \mathrm{W}\right)$, San Lorenzo (08 $53^{\prime} 20,0^{\prime \prime}$ $\mathrm{N} 076^{\circ} 18^{\prime} 42,6^{\prime \prime} \mathrm{W}$ ), and El Refugio (08 $\left.32^{\prime} 44,3^{\prime \prime} \mathrm{N} 075^{\circ} 20^{\prime} 39,9^{\prime \prime} \mathrm{W}\right)$. These specimens are the result of undergrad (RÍOS-
BLANCO, 2010; OLAYA-RODRÍGUEZ, 2009), master (CALONGE, 2012; VELA-VARGAS, 2013) and doctoral thesis (BALLESTEROSCORREA, 2015).

Specimen selection. Exclusion criteria were used in order to avoid noise factors such as developmental stage, misleading taxonomic identification, and specimens badly preserved. In doing so, bat vouchers selected were only adults, according to data of the tags and field notebooks of each specimen. The identification of each specimen was corroborated with the keys of GARDNER (2007). All specimens in bad state of preservation (i.e. broken wings) were excluded from data analysis.

Wing traits. To analyze FA, 11 wing traits were measured from both right and left sides (Figure 1). The measurements were taken with a digital caliper (Mitutoyo Calibrador Vernier Mod Cd6 -csX 150 Mm) with an accuracy of $0.01 \mathrm{~mm}$ and were done by the same researcher (Dennis Castillo-Figueroa).

Data analysis. After testing the assumptions of normality (Shapiro-Wilk test) and homoscedasticity (Levene test), wing traits data were nonparametric. Hence, to assess the existence of fluctuating asymmetry between the right and left sides of bat wings, nonparametric $U$ test of Wilcoxon-Mann-

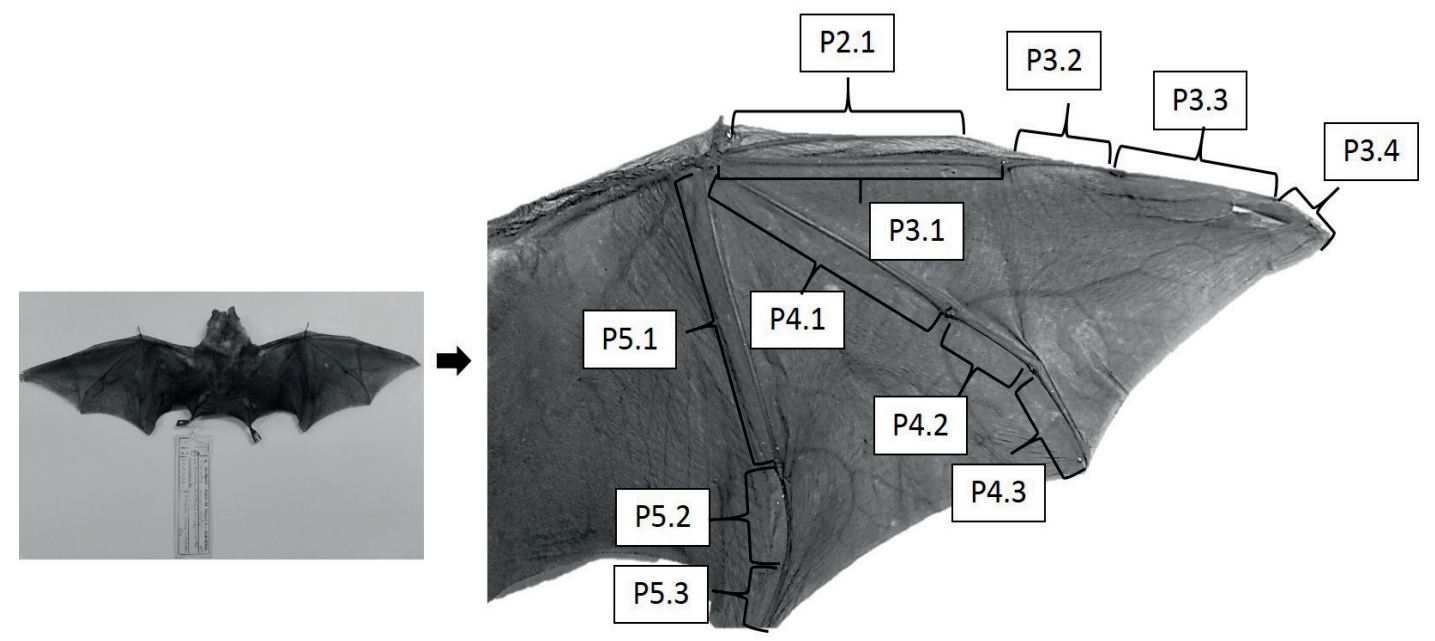

Figure 1. Wing traits used for fluctuating asymmetry analysis. P2.1 Second digit, metacarpal. P3.1 Third digit, metacarpal. P3.2 Third digit, first phalanx. P3.3 Third digit, second phalanx. P3.4 Third digit, third phalanx P4.1 Fourth digit, metacarpal P4.2 Fourth digit, first phalanx P4.3 Fourth digit, second phalanx P5.1 Fifth digit, metacarpal P5.2 Fifth digit, first phalanx P5.3 Fifth digit, second phalanx. 
Whitney was applied. The null hypothesis for this test establishes no significant differences between the means of wing sides for each trait (FIGUEIREDO et al., 2015). Statistical means and standard deviations are presented for right and left sides of each wing trait.

To evaluate the existence of significant differences among digits of bat wings, the traits were grouped into the following categories: III digit (P3.1+P3.2+P3.3+P3.4), IV digit (P4.1+P4.2+P4.3) and $V$ digit (P5.1+P5.2+P5.3). These categories present metacarpals and phalanges that support the main structure of dactylopatagium, which is important for flight performance (NORBERG and RAYNER, 1987). Therefore, a general analysis of bat wing asymmetry was conducted, through the three principal digits that support this wing membrane. The asymmetry value was calculated according to PALMER (1994):

$$
F A=|R-L|
$$

In the formula, FA is the fluctuating asymmetry value, $R$ is the measurement of the right side of the wing, as well as $L$ represents the left side of the wing. Nonparametric one-way analysis of variance was done (KruskalWallis), taking the digit as the factor and the
III, IV and V digits as the levels of the factor. In all the tests, $p<0.05$ defined the level of statistically significant difference. All the analysis presented here, were done separately for males and females in the statistical software Rwizard 2.1. Because of some works have shown sexual dimorphism in Neotropical bats based on wing traits (CAMARGO and OLIVEIRA, 2012; STEVENS et al., 2013), multivariate analysis of variance (MANOVA) was conducted in InfoStat 1.0. Due to wing traits were nonparametric, transformations of all variables to normal scores ( $z$ values) were done in order to use MANOVA test.

\section{RESULTS}

In total, 114 bat specimens were analyzed: 33 of $A$. lituratus (15 males, 18 females), 40 of $A$. planirostris ( 15 males, 25 females), and 41 of $C$. perspicillata (21 males, 20 females). The nonparametric Wilcoxon-Mann-Whitney test only showed the existence of significant differences between wing sides of the first phalanx of the third digit in males (P3.2) and the third phalanx of the third digit (P3.4) in females of $C$. perspicillata $(p<0.05$, Table $1)$. For both Artibeus species there were no statistical differences in any wing trait (Table 2 and 3 ).

Table 1. Wing traits of Carollia perspicillata specimens in extensive livestock systems (Córdoba, Colombia).

\begin{tabular}{ccccccccc}
\hline \multirow{2}{*}{ Wing traitsts } & \multicolumn{9}{c}{ Males } & \multicolumn{5}{c}{ Females } \\
\cline { 2 - 9 } & Right & Left & $\mathbf{U}$ & $\mathbf{p}$ & Right & Left & $\mathbf{U}$ & $\mathbf{p}$ \\
\hline P2.1 & $31.58 \pm 1.65$ & $31.42 \pm 1.65$ & 217 & 0.949 & $30.41 \pm 2.09$ & $29.94 \pm 1.74$ & 229 & 0.445 \\
P3.1 & $36.67 \pm 1.02$ & $36.51 \pm 1.18$ & 241 & 0.614 & $36.22 \pm 1.76$ & $36.35 \pm 1.72$ & 178 & 0.560 \\
P3.2* & $15.65 \pm 0.66$ & $15.14 \pm 0.69$ & 306 & $\mathbf{0 . 0 3 2}$ & $15.41 \pm 0.95$ & $15.21 \pm 0.67$ & 242 & 0.261 \\
P3.3 & $20.51 \pm 0.78$ & $20.18 \pm 0.86$ & 266 & 0.252 & $20.37 \pm 1.03$ & $19.90 \pm 1.13$ & 250 & 0.176 \\
P3.4* & $12.61 \pm 1.12$ & $12.46 \pm 0.75$ & 253 & 0.420 & $12.76 \pm 0.66$ & $11.47 \pm 2.07$ & 317 & $\mathbf{0 . 0 0 1}$ \\
P4.1 & $35.05 \pm 1.27$ & $35.09 \pm 1.39$ & 206 & 0.727 & $35.03 \pm 1.82$ & $35.08 \pm 1.94$ & 188 & 0.766 \\
P4.2 & $12.30 \pm 0.45$ & $12.12 \pm 0.55$ & 263 & 0.285 & $12.42 \pm 0.59$ & $12.15 \pm 0.68$ & 234 & 0.357 \\
P4.3 & $13.35 \pm 0.95$ & $13.15 \pm 0.78$ & 238 & 0.668 & $13.42 \pm 0.90$ & $13.22 \pm 1.19$ & 208 & 0.828 \\
P5.1 & $37.42 \pm 1.31$ & $37.68 \pm 1.31$ & 198 & 0.583 & $37.07 \pm 2.21$ & $37.49 \pm 2.15$ & 168 & 0.398 \\
P5.2 & $11.17 \pm 0.62$ & $10.91 \pm 0.60$ & 274 & 0.182 & $11.16 \pm 0.64$ & $10.86 \pm 0.58$ & 253 & 0.155 \\
P5.3 & $12.30 \pm 1.17$ & $12.20 \pm 0.91$ & 235 & 0.715 & $12.11 \pm 1.02$ & $12.05 \pm 1.09$ & 210 & 0.786 \\
\hline
\end{tabular}

Statistical mean \pm standard deviation for Right and Left wings presented in millimeters $(\mathrm{mm})$. $U=$ Non-parametric $U$ test. $p=$ Significance level of Wilcoxon-Mann-Whitney test. * Statistical differences. 
Castillo-Figueroa - Fluctuating asymmetry of three bat species in extensive livestock systems

Table 2. Wing traits of Artibeus lituratus specimens in extensive livestock systems (Córdoba, Colombia).

\begin{tabular}{ccccccccc}
\hline \multirow{2}{*}{ Wing traits } & \multicolumn{1}{c}{ Males } & \multicolumn{3}{c}{ Females } \\
\cline { 2 - 9 } & Right & Left & $\mathbf{U}$ & $\mathbf{p}$ & Right & Left & U & p \\
\hline P2.1 & $57.11 \pm 3.29$ & $56.83 \pm 3.26$ & 117 & 0.870 & $61.15 \pm 2.04$ & $59.81 \pm 2.11$ & 216 & 0.087 \\
P3.1 & $61.72 \pm 3.58$ & $61.55 \pm 3.59$ & 112 & 1 & $64.10 \pm 1.42$ & $63.41 \pm 1.38$ & 208 & 0.151 \\
P3.2 & $21.61 \pm 1.71$ & $21.28 \pm 1.34$ & 136 & 0.329 & $22.76 \pm 0.98$ & $22.17 \pm 1.27$ & 201 & 0.226 \\
P3.3 & $34.65 \pm 2.75$ & $34.62 \pm 2.71$ & 116 & 0.900 & $36.13 \pm 1.21$ & $35.87 \pm 1.35$ & 182 & 0.526 \\
P3.4 & $22.70 \pm 2.43$ & $22.70 \pm 2.00$ & 121 & 0.724 & $24.21 \pm 1.89$ & $23.97 \pm 1.73$ & 183 & 0.516 \\
P4.1 & $60.74 \pm 3.50$ & $61.05 \pm 3.56$ & 102 & 0.682 & $62.54 \pm 1.52$ & $62.84 \pm 1.33$ & 147 & 0.657 \\
P4.2 & $18.29 \pm 1.32$ & $17.88 \pm 1.42$ & 139 & 0.280 & $19.12 \pm 0.90$ & $18.68 \pm 0.70$ & 203 & 0.194 \\
P4.3 & $23.79 \pm 2.30$ & $23.52 \pm 2.72$ & 112 & 1 & $25.49 \pm 1.28$ & $25.01 \pm 1.24$ & 204 & 0.189 \\
P5.1 & $63.65 \pm 3.85$ & $63.54 \pm 3.96$ & 115 & 0.917 & $64.93 \pm 1.68$ & $64.93 \pm 1.78$ & 174 & 0.716 \\
P5.2 & $13.98 \pm 1.09$ & $13.73 \pm 1.07$ & 132 & 0.436 & $14.77 \pm 0.88$ & $14.50 \pm 0.80$ & 200 & 0.229 \\
P5.3 & $20.07 \pm 1.62$ & $19.34 \pm 1.52$ & 142 & 0.229 & $20.22 \pm 2.27$ & $20.19 \pm 1.29$ & 167 & 0.874 \\
\hline
\end{tabular}

Statistical mean \pm standard deviation for Right and Left wings presented in millimeters $(\mathrm{mm})$. $U=$ Non-parametric $U$ test. $p=$ Significance level of Wilcoxon- Mann-Whitney test.

Table 3. Wing traits of Artibeus planirostris specimens in extensive livestock systems (Córdoba, Colombia).

\begin{tabular}{ccccccccc}
\hline \multirow{2}{*}{ Wing traits } & \multicolumn{2}{c}{ Males } & & & & Females \\
\cline { 2 - 8 } & Right & Left & U & p & Right & Left & U & p \\
\hline P2.1 & $50.63 \pm 2.45$ & $51.14 \pm 2.97$ & 101 & 0.663 & $51.63 \pm 3.10$ & $50.80 \pm 3.33$ & 300 & 0.815 \\
P3.1 & $54.11 \pm 2.08$ & $53.89 \pm 2.24$ & 117 & 0.851 & $55.03 \pm 3.21$ & $54.65 \pm 3.17$ & 0.37 & 0.375 \\
P3.2 & $17.84 \pm 0.98$ & $17.40 \pm 0.80$ & 138 & 0.290 & $18.32 \pm 1.25$ & $17.93 \pm 1.34$ & 333 & 0.698 \\
P3.3 & $28.75 \pm 1.24$ & $28.83 \pm 2.31$ & 128 & 0.520 & $29.48 \pm 2.24$ & $28.99 \pm 2.59$ & 328 & 0.771 \\
P3.4 & $19.99 \pm 1.48$ & $20.24 \pm 1.37$ & 101 & 0.652 & $20.55 \pm 2.02$ & $20.70 \pm 1.96$ & 302 & 0.853 \\
P4.1 & $52.84 \pm 2.25$ & $53.36 \pm 2.14$ & 98 & 0.566 & $53.77 \pm 3.19$ & $54.08 \pm 3.06$ & 288 & 0.641 \\
P4.2 & $15.59 \pm 0.81$ & $15.20 \pm 0.70$ & 142 & 0.221 & $15.86 \pm 0.81$ & $15.50 \pm 0.94$ & 397 & 0.101 \\
P4.3 & $22.06 \pm 0.80$ & $21.87 \pm 0.80$ & 131 & 0.442 & $21.97 \pm 1.90$ & $21.84 \pm 1.87$ & 331 & 0.719 \\
P5.1 & $55.29 \pm 2.23$ & $55.31 \pm 2.19$ & 116 & 0.884 & $56.20 \pm 3.27$ & $56.41 \pm 3.12$ & 300 & 0.815 \\
P5.2 & $11.85 \pm 0.50$ & $11.49 \pm 0.65$ & 155 & 0.077 & $12.00 \pm 0.75$ & $11.65 \pm 0.73$ & 397 & 0.103 \\
P5.3 & $17.28 \pm 0.80$ & $16.95 \pm 0.91$ & 132 & 0.430 & $17.54 \pm 1.77$ & $17.18 \pm 1.61$ & 342 & 0.573 \\
\hline
\end{tabular}

Statistical mean \pm standard deviation for Right and Left wings presented in millimeters $(\mathrm{mm})$. $U=$ Non-parametric $U$ test. $p=$ Significance level of Wilcoxon- Mann-Whitney test.

For the digit analysis, only the females of $A$. planirostris presented significant differences $(\mathrm{H}=3.370, \mathrm{p}=0.035$, Figure 2). In the other two species, there were no significant difference between the digits in terms of fluctuating asymmetry values (Figure 2).
On the other hand, $A$. lituratus was the unique of the three bat species analyzed, which showed sexual dimorphism according to wing traits (Wilks' Lambda $=0.72, \mathrm{~F}=2.83$, $\mathrm{p}=0.01)$. For all the wing measurements, females presented higher values in the statistical means than males (Table 2 ). 


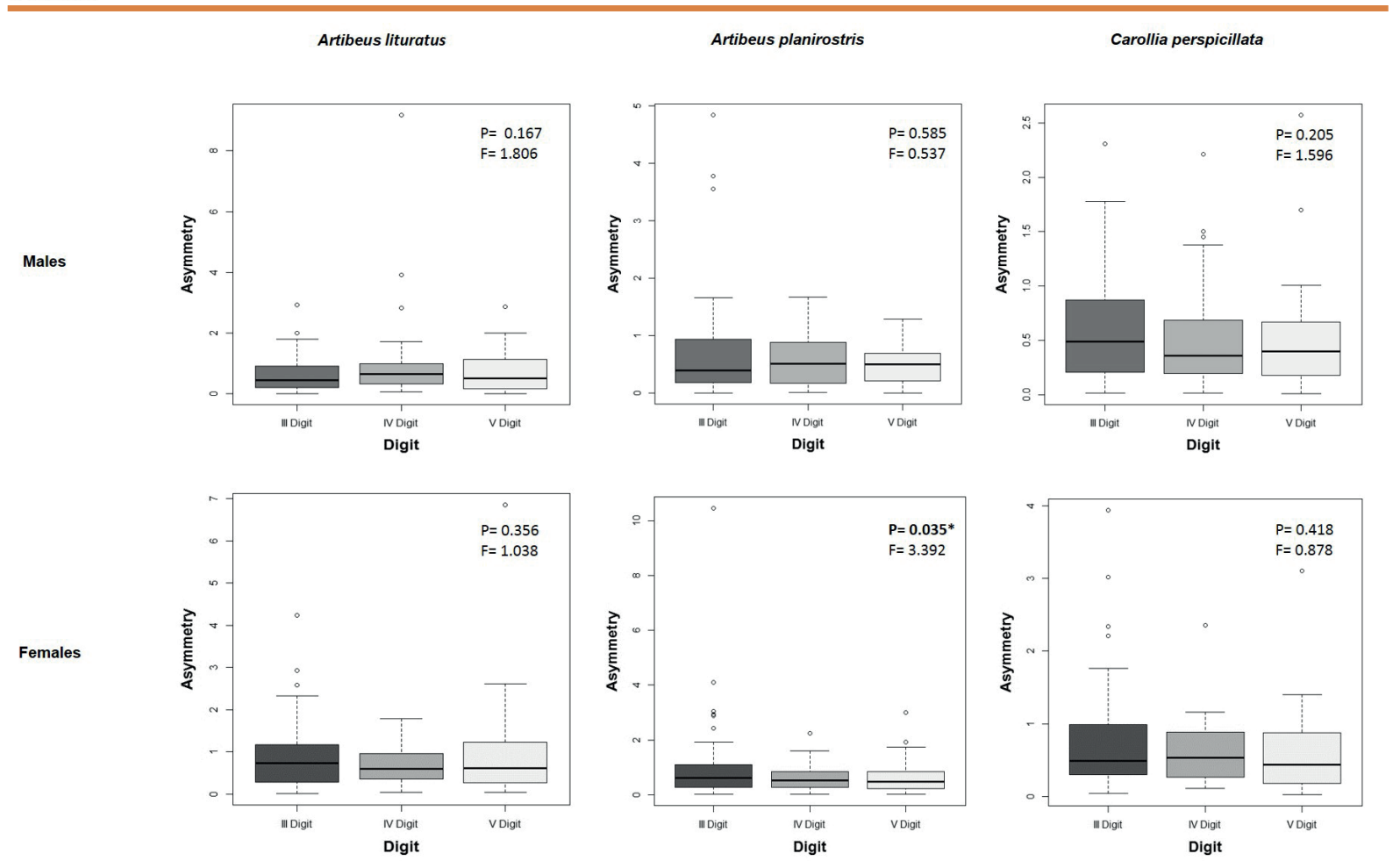

Figure 2.Box-plots for asymmetry values of the III, IV and $\mathrm{V}$ digits in females and males of Artibeus planirostris, Artibeus lituratus and Carollia perspicillata specimens in extensive livestock systems (Córdoba, Colombia). $\mathrm{p}=$ Significance level of Kruskal-Wallis. $\mathrm{H}=$ Kruskal-Wallis test.

By contrast, neither $A$. planirostris (Wilks' Lambda $=0.88, F=0.95, p=0.494$ ) nor $C$. perspicillata (Wilks' Lambda $=0.89, \mathrm{~F}=0.89$, $p=0.548$ ) presented sexual dimorphism in wing traits.

\section{DISCUSSION}

Fluctuating asymmetry of bat species and their tolerance to habitat perturbations. In general terms, the results showed no statistical difference $(p>0,05)$ in most of the wing traits, suggesting that environmental conditions of tropical dry-forest fragments immersed in extensive livestock systems, were not enough to cause several changes in the wing morphology of these bat species. One of the possible reasons of the low degree of asymmetry is that natural selection may favor symmetrical individuals rather than asymmetrical. The "Differential-mortality" hypothesis establishes that individuals with less FA have more possibilities for survival unlike individuals with high FA (FLOATE and FOX, 2000). Symmetry may favor the locomotion leading a better ability for flight performance and food capture (VOIGT et al., 2005). Hence, the selective pressure on bats eliminates asymmetrical individuals, selecting symmetrical ones for next generations (VOIGT et al., 2005), which are probably the specimens analyzed in this work.

Additionally, variation in wing traits is more conservative due to its functionality on flight performance (NORBERG and RAYNER, 1987), thermoregulation (MAKANYA and MORTOLA, 2007), and food manipulation (VANDOROS and DUMONT, 2004). Comparing with other body regions such as head and hind-limbs, forelimbs have less asymmetry in bats (FIGUEIREDO et al., 2015).

Moreover, the three bat species are common frugivorous with a wide geographical distribution throughout the country (MUÑOZ, 2001). Typically, C. perspicillata 
Castillo-Figueroa - Fluctuating asymmetry of three bat species in extensive livestock systems

PEEAP

and $A$. lituratus are often used as ecological indicators of fragmented landscapes (GALINDO, 2004). All the three species are reported in different environments such as monocultures (BREVIGLIERI and UIEDA, 2014; ORTEGÓN-MARTÍNEZ and PÉREZ-TORRES, 2007), urban systems (FIGUEIREDO et al., 2015; ALBERICO et al., 2005) and extensive livestock systems (BALLESTEROS-CORREA, 2015). Based on the findings of this research, but also on the high abundances of these bat species reported for extensive livestock systems (BALLESTEROS-CORREA, 2015), it is possible to infer that, at first glance, these species are not hampered by livestock systems because of their high tolerance to habitat perturbation. Further studies should evaluate the FA of bat species from other guilds (e.g. insectivores, carnivores, nectarivores, omnivores), and with other ecological characteristics (e.g. high habitat specificity, rare species), to test differential responses of species to livestock systems.

Some differences in wing traits and sexual dimorphism. Differences were detected in two wing traits of the third digit for C. perspicillata (P3.2, P3.4, Table 1). The third digit is a measure of hand-wing length and enable $a$ fast and economic flight (DIETZ et al., 2006). Recently, it has been found a wing defect (i.e. nonsymmetrical digit) in specimens of $C$. perspicillata associated to livestock systems (CASTILLOFIGUEROA and PÉREZ-TORRES, 2018). This wing anomaly refers to the difference of the length in P3.4 between left and right side (CASTILLO-FIGUEROA and PÉREZ-TORRES, 2018), which is the wing trait that showed statistical difference in the present study (Table 1).

For $A$. planirostris, other studies conducted in urban environments from Brazil neither found a high asymmetry (FIGUEIREDO et al., 2015). The present study shows the low degree of stress for this species in extensive livestock systems, only with statistical difference between the digits of females (Figure 2), but without differences in the individual wing traits for both males and females (Table 3 ). A. planirostris exhibits a great ecological plasticity using a variety of roost structures in sites with high availability of food (BREVIGLIERI and UIEDA, 2014). In this sense, fragments of tropical dryforest may provide enough food source for developmental stability in this species.

On the other hand, females of $A$. lituratus showed for all the statistical means of wing traits, higher values compared with males (Table 2). The "Big Mother" hypothesis proposes that larger females have greater reproductive success, because they can birth larger offspring and bring a greater amount of resources to them (RALLS, 1976). Previously, STEVENS et al. (2013) demonstrated the existence of this phenomenon using wing traits of $A$. lituratus from 15 sites in eastern Paraguay and five sites in north-eastern Argentina. This study highlighted that larger wing traits are useful for better flight performance in females to forage resources, carrying babies, and compensate a higher body weight (STEVENS et al., 2013). The results presented here support the "Big Mother" hypothesis for $A$. lituratus in terms of wing traits.

Final considerations. The asymmetry analysis with multiple traits provides better understanding of the influence of stress (STAMOUR et al., 2010; LEUNG et al., 2000; LEARY and ALLENDORF, 1989). In this study, detailed analyzes of 11 wing traits were conducted (i.e. metacarpals and phalanges), but also general analyzes using three main structures of the wings were made (i.e. III digit, IV digit, $V$ digit).

One of the limitations of the present study is the low sample size, which can affect the detection of normality deviations (BENÍTEZ and PARRA, 2011; GRAHAM et al., 2010). However, this issue depends mainly on the specimens available in biological collections (CASTILLO-FIGUEROA, in press; PYKE and EHRLICH, 2010), being outside the researcher's control. It is important to increase the number of specimens in museum collections for address, robustly, different ecological questions using more samples. This study shows the relevance of biological collections in the contribution of key data, which can be useful to parse out the effect of landscape transformation 
on the ecological responses of species (CASTILLO-FIGUEROA, in press).

In conclusion, wing traits of these bat species did not show a considerably asymmetry in tropical dry-forest fragments immersed in extensive livestock systems of Cordoba department. The results of this work suggest a low degree of stress for the three bat species, and highlight that livestock systems do not severely affect them due to their high tolerance to habitat perturbation. Nevertheless, this study did not distinguish the type of management of extensive livestock system. It would be important to compare silvopastoral management with conventional management to know, with more detail, if someone of them provides better conditions for bat species. Finally, it would be important to consider bat species of other guilds and with a high habitat specificity, because in the present study only frugivorous and common species were considered.

\section{Acknowledgements}

Special thanks to Jairo Pérez-Torres, the curator of the Mammalian Collection of Museo Javeriano de Historia Natural from Pontificia Universidad Javeriana (Bogotá, Colombia), for allowing me access the specimens of the collection. I also thank to William Figueroa for the revision of the English text and the anonymous reviewer for helpful comments on the manuscript.

\section{REFERENCES}

ALBERICO, M.; SAAVEDRA-R, C.A.; GARCÍA-PAREDES, H. 2005. House bats of Cali, Colombia. Caldasia 27 (1): 117-126.

BALLESTEROS-CORREA, J. 2015. Efecto del manejo silvopastoril y convencional de ganadería extensiva sobre el ensamblaje de murciélagos asociados a fragmentos de bosque seco tropical en Córdoba, Colombia. Tesis doctoral. Bogotá: Pontificia Universidad Javeriana, Ciencias biológicas.

BENÍTEZ, H. A.; PARRA, L. E. Asimetría fluctuante: una herramienta morfo-funcional para medir estabilidad del desarrollo. Int. J.Morphol 29 (4): 1459-1469, 2011.

BREVIGLIERI, C.P.B.; UIEDA, W. 2014. Tree cavities used as diurnal roosts by Neotropical bats. Folia Zool 63 (3): 206-215.

CALONGE, B. 2012. Ectoparásitos de murciélagos presentes en fragmentos de bosque seco tropical en manejos de ganadería convencional y silvopastoril (Córdoba, Colombia). Tesis de Maestría. Bogotá: Pontificia Universidad Javeriana, Ciencias biológicas.

CAMARGO, N.; OLIVEIRA, H. 2012. Sexual dimorphism in Sturnira lilium (Chiroptera, Phyllostomidae): can pregnancy and pup carrying be responsible for differences in wing shape? Plos one 7 (11): e49734.

CASTILLO-FIGUEROA, D. In press. Beyond specimens: linking biological collections, functional ecology and biodiversity conservation. Revista Peruana de Biología.

CASTILLO-FIGUEROA, D.; PÉREZ-TORRES, J. 2018. First records of wing defects in phyllostomid bats from Colombia. Journal of Bat Research \& Conservation 11 (1). Available in URL: http://secemu.org/wp-content/uploads/2018/05/CastilloFigueroa_ et_al_2018.pdf. 
CEBALLOS, G.; EHRLICH, P.; DIRZO, R. 2017. Biological annihilation via the ongoing sixth mass extinction signaled by vertebrate population losses and declines. Proceedings of the National Academy of Sciences 114 (30): E6089-E6096.

CODA, J.; GOMEZ, D.; MARTÍNEZ, J.J.; STEINMANN A.; PRIOTTO, J. 2016. The use of fluctuating asymmetry as a measure of farming practice effects in rodents: a speciesspecific response. Ecological Indicators 70: 269-275.

DIETZ, C.; DIETZ, I.; SIEMERS B.J. 2006. Wing measurement variations in the five european horseshoe bat species (Chiroptera: Rhinolophidae). Journal of Mammalogy 87 (6): 1241-1251.

ETTER, A., ANDRADE, A., AMAYA, P., ARÉVALO, P. 2015. Estado de los ecosistemas colombianos 2014: una aplicación de la metodología de lista roja de ecosistemas. (Cited 6 Nov 2017) Available in URL: https://iucnrle.org/static/media/uploads/references/publishedassessments/etter-etal-2015-national-rle-assessment-final-report-colombia-sp.pdf

FLOATE, K.D.; FOX, A.S. 2000. Flies under stress: a test of fluctuating asymmetry as a biomonitor of environmental quality. Ecological Applications 10 (5): 1541-1550.

FIGUEIREDO, D.; GONÇALVES MILLER, B.; BARBOSA LEAL, E.S.; MONTES, M.A. 2015. Fluctuating asymmetry in populations of bats: species adapted to urban environments are not hampered by habitat degradation. Chiroptera Neotropical 21 (1): 1305-1311.

GALINDO, J.G. 2004. Clasificación de los murciélagos de la región de Los Tuxtlas, Veracruz, respecto a su respuesta a la fragmentación del hábitat. Acta Zoológica Mexicana 20 (2): 239-243.

GARDNER, A.L. 2007. Mammals of South America. Volume 1: Marsupials, Xenarthrans, Shrews, and Bats. The University of Chicago Press, Chicago.

GÓMEZ, M.F.; MORENO, L.A. 2016. Biodiversidad 2015 en cifras. Page: 13. in: GÓMEZ, M.F.; MORENO, L.A.; ANDRADE, G.I.; RUEDA, C. (Eds.). Biodiversidad 2015. Estado $y$ tendencias de la biodiversidad continental de Colombia. Instituto Alexander von Humboldt. Bogotá, D.C., Colombia.

GRAHAM, J.H.; RAZ, S.; HEL-OR, H.; NEVO, E. 2010. Fluctuating asymmetry: methods, theory, and applications. Symmetry 2 (2): 466-540.

LAZIC, M.M.; KALIONTZOPOULOU, A.; CARRETERO, M.A.; CRNOBRNJA-ISAILOVI'C, J. 2013. Lizards from urban areas are more asymmetric: using fluctuating asymmetry to evaluate environmental disturbance. Plos one 8 (12): e84190.

LEARY, R.F.; ALLENDORF, F.W. 1989. Fluctuating asymmetry as an indicator of stress: implications for conservation biology. Trends in Ecology and Evolution 4 (7): 214-217.

LENS, L.; VAN DONGEN, S.; WILDER, C.M.; BROOKS, T.M.; MATTHYSEN, E. 1999. Fluctuating asymmetry increases with habitat disturbance in seven bird species of a fragmented afrotropical forest. Proceedings of the Royal Society of London Series B 266 (1425): 1241-1246.

LEUNG, B.; FORBES, M.R.; HOULE, D. 2000. Fluctuating asymmetry as a bioindicator of stress: comparing efficacy of analyses involving multiple traits. The American Naturalist 155 (1): 101-115. 
MAKANYA, A.; MORTOLA, J. 2007. The structural design of the bat wing web and its possible role in gas exchange. Journal of Anatomy 211 (6): 687-697.

MARINELLO, M.M.; BERNARD, E. 2014. Wing morphology of Neotropical bats: a quantitative and qualitative analysis with implications for habitat use. Canadian Journal of Zoology 92 (2): 141-147.

MESSIER, S.; MITTON, J.B. 1996. Heterozygosity at the malate dehydrogenase locus and developmental homeostasis in Apis mellifera. Heredity 76: 616-622.

MUÑOZ, J. 2001. Los murciélagos de Colombia: Sistemática, distribución, descripción, historia natural y ecología. Universidad de Antioquia. Medellín.

NORBERG, U.M.; RAYNER, J.M. 1987. Ecological morphology and flight in bats (Mammalia: Chiroptera): wing adaptation, flight performance, foraging strategy and echolocation. Philosophical Transactions of the Royal Society B. 316 (1179): 335-427.

OLAYA-RODRÍGUEZ, H. 2009. Análisis de la estratificación vertical del ensamblaje de murciélagos de un fragmento de bosque seco tropical (Córdoba, Colombia) a partir de la heterogeneidad de hábitat y la ecomorfología alar. Trabajo de grado. Bogotá: Pontificia Universidad Javeriana, Biología.

ORTEGÓN-MARTÍNEZ, D.; PÉREZ-TORRES, J. 2007. Estructura y composición del ensamblaje de murciélagos (Chiroptera) asociados a un cafetal con sombrío en la mesa de los santos (Santander), Colombia. Actualidades Biológicas 29 (87): 215-228

PALMER, A. R. 1994. Fluctuating asymmetry analyses: A primer. Pages: 335-364, in: MARKOW T.A. (Eds) Developmental Instability: Its Origins and Evolutionary Implications. Kluwer, Dordrecht, Netherlands.

PIZANO, C.; GARCÍA H. 2014. El Bosque Seco Tropical en Colombia. Instituto de Investigación de Recursos Biológicos Alexander von Humboldt (IAvH), Bogotá.

PYKE, G.H.; EHRLICH, P.R. 2010. Biological collections and ecological/environmental research: a review, some observations and a look to the future. Biological Review 85 (2): 247-266.

RALLS, K. 1976. Mammals in which females are larger than males. Quarterly Review of Biology 51 (2): 245-276.

RANGEL-CH, O. 2015. La biodiversidad de Colombia: significado y distribución regional. Revista de la Academia Colombiana de Ciencias Exactas Físicas y Naturales 39 (151): 176-200.

RÍOS-BLANCO, M.C. 2010. Dieta y dispersión de semillas por murciélagos frugívoros en un fragmento de bosque seco tropical. Córdoba, Colombia. Trabajo de grado. Bogotá: Pontificia Universidad Javeriana, Biología.

STEVENS, R.; JOHNSON, M.; MCCULLOCH, E. 2013. Absolute and relative secondary-sexual dimorphism in wing morphology: a multivariate test of the 'Big Mother' hypothesis. Acta Chiropterologica 15 (1): 163-170. 
ST- AMOUR, V.; GARNER, T.W.; SCHULTE-HOSTEDDE, A.I.; LESBARRĖRES, D. 2010. Effects of two amphibian pathogens on the developmental stability of green frogs. Conservation Biology 24 (3): 788-94.

THORNTON, P.K.; VAN DE STEEG, J.; NOTENBAERT, A.; HERRERO, M. 2009. The impacts of climate change on livestock and livestock systems in developing countries: A review of what we know and what we need to know. Agricultural Systems 101 (3): 113-127.

VANDOROS, J.D.; DUMONT, E.R. 2004. Use of the wings in manipulative and suspensory behaviors during feeding by frugivorous bats. Journal of experimental Zoology 301 (4): 361-366.

VELA-VARGAS, M. 2013. Variaciones en la fenología reproductiva de las especies de murciélagos en dos sistemas ganaderos: efecto de la disponibilidad de recursos. Tesis de Maestría. Bogotá: Pontificia Universidad Javeriana. Ciencias biológicas.

VOIGT, C. C.; HECKEL, G.; MAYER, F. 2005. Sexual selection favours small and symmetric males in the polygynous greater sac-winged bat Saccopteryx bilineata (Emballonuridae, Chiroptera). Behavioral Ecology and Sociobiology 57 (5): 457-464.

WANG, Z.; DONG, D.; RU, B.; YOUNG, R.; HAN, N.; GUO, T.; ZHANG, S. 2010. Digital gene expression tag profiling of bat digits provides robust candidates contributing to wing formation. BMC Genomics 11: 619.

WAUTERS, L.A.; DHONDT, A.A.; KNOTHE, H.; PARKIN, D.T. 1996. Fluctuating asymmetry and body size as indicators of stress in red squirrel populations in woodland fragments. Journal of applied ecology 33 (4): 735-740. 